\title{
MONITORING OF HEAVY METALS, EOX AND LAS IN SEWAGE SLUDGE FOR AGRICULTURAL USE: A CASE STUDY
}

\author{
Ali Khakbaz 1,2, Maria De Nobili ${ }^{2}$, Matia Mainardis ${ }^{1}$, Marco Contin ${ }^{2}$, Eleonora Aneggi 1,*, \\ Michele Mattiussi ${ }^{3}$, Igino Cabras ${ }^{3}$, Marco Busut ${ }^{3}$ and Daniele Goi ${ }^{1}$ \\ 1 Department Polytechnic of Engineering and Architecture, University of Udine, via del Cotonificio 108, 33100 Udine, Italy \\ 2 Department of Agricultural, Food, Environmental and Animal Sciences (DI4A), University of Udine, via delle Scienze 208, 33100 \\ Udine, Italy \\ ${ }^{3}$ Arpa FVG - Laboratorio Analisi Ambientali e Matrici Sanitarie, via Colugna 42, 33100 Udine, Italy
}

Article Info:
Received:
25 September 2019
Revised:
24 March 2020
Accepted:
25 March 2020
Available online:
24 July 2020
Keywords:
Sewage sludge
Heavy metals
Extractable organic halogen
Alkylbenzene sulphonate
Sustainable agriculture

\section{INTRODUCTION}

From the perspective of sustainable agriculture, reuse of sewage sludge is fundamental due to nutritional and organic matter content (Fijalkowski et al., 2017) and low cost. However, the persistent presence of a series of organic contaminants and toxic elements in sewage sludge may result in environmental and health issues (Anjum et al., 2016). Wastewater treatment plants (WWTPs) are in continuous development, with ongoing construction of new treatment units or upgrading of existing facilities. Sludge management has become one of the most critical environmental issues in the sector. Indeed, nowadays, approximately $50 \%$ of total operating costs in WWTPs are incurred in sludge treatment (Quian et al., 2016). In Europe in 2015, approx. 9.5 million tons dry matter of sewage sludge were produced (Eurostat, 2018), thus requiring appropriate disposal.

Several options are available for use in the final disposal of sewage sludge, including energy and resource recovery (Abis et al., 2018; Di Maria et al., 2018; Gherghel et al., 2019; Haarlemmer et al., 2018). Specifically, treated sludge, when applied as fertiliser and soil conditioner are a source of nutrients for the soil, (Yoshida et al., 2018; Ashekuzzaman et al., 2019), although the risks of soil contamination and pathogen transmission should be carefully considered (Singh and Agrawal, 2008; Tsybina and Wuensch, 2018). Council Directive 91/271/EEC encouraged the land application of sewage sludge (European Commission, 1991) due to the related fertilizing and conditioning properties for agricultural soil. However, this practice may also lead to environmental and health risks, due to accumulation of persistent organic contaminants, toxic elements (Valentin et al., 2013) and heavy metals (Chen and Hu, 2019) contained in sewage sludge. When sludge produced by urban WWTPs is used as fertilizer in agriculture, a detailed specification of the properties and quality of sludge is required (USEPA, 1995; American Society of Civil Engineers and American Water Works Association, 1996) to prevent the onset of health and environmental issues. In a study by Laura et al. (2020), decision support framework was used to analyse different strategies for sewage sludge handling in Latin America; a pool of different parameters was considered, including economic, social, environmental and technological 
aspects. Given local peculiar sludge characteristics, such as low HM content and high pathogenic contamination, the application of a composting process before agricultural reuse was recommended as the best solution for managing sludge valorisation (Laura et al., 2020). A study by Collivignarelli et al. (2020), investigated a sewage sludge management chain in the Pavia province, Italy, highlighting the most critical issues for agricultural application, including a need to promote global sludge reduction in WWTPS, the production of sludge with standardized characteristics, together with a better selection of materials in dedicated sludge treatment plants and an increased control of agricultural soil response (Collivignarelli et al., 2020).

A major cause of concern is related to the toxicity of heavy metals even at trace concentrations (order of magnitude of $\mathrm{ng} / \mathrm{L}$ ), in particular Cd, given its high bioavailability (Hu et al., 2017). Heavy metals such as lead, cadmium, mercury, nickel and chromium (Pires and Mattiazzo, 2003; Singh et al., 2004; Hargreaves et al., 2018) in municipal wastewater originate from household sewage, industrial wastewater or urban runoff (Sorme and Lagerkvist, 2002). The majority of these toxic metals accumulate in the sludge, since only a small amount is released with the treated final effluent (Sorme and Lagerkvist, 2002). Once sludge from WWTPs are applied to the soil, the degradation of organic compounds in sewage sludge affects the availability of heavy metals, inducing accumulation in plant biomass, one of the primary elements of the human food chain (Gondek et al., 2014). A recent study by Romanos et al. (2019) highlighted that to reduce metals and pathogenic microorganisms in sludge in line with strict legislative limits, further processing (such as composting) may be required.

Recently, particular focus has been concentrated on organic compounds present in domestic and municipal wastewater due to their accumulation in sludge. The use of some parameters, such as Extractable Organic Halogen (EOX) (Kannan et al., 1999; Niemirycz et al., 2005) and Linear Alkylbenzene Sulphonate (LAS), is particularly meaningful, in view of their good representation of a general wide-ranging organic pollution in sludge.

The importance and usefulness of EOXs in the assessment of environmental quality have been demonstrated in a series of studies (Rodziewicz et al., 2004; Contreras Lopez, 2003; Goi et al., 2006; Rizzardini and Goi, 2014; Braguglia et al., 2014); however, a limited number of investigations have addressed the issue of EOX content in sludge. Sewage sludge application in agriculture represents the main source of LAS entrance to agricultural soil (Jensen, 1999). Sludge concentrations of the latter are strictly dependent on sludge treatment applied, with higher degradation observed under aerobic conditions: commonly found LAS concentrations are $1,000-30,000 \mathrm{mg} / \mathrm{kg}$ in anaerobically digested sludge; $<1,000 \mathrm{mg} / \mathrm{kg}$ in aerobic sludge and $<500$ $\mathrm{mg} / \mathrm{kg}$ (dry weight) in aerobically stabilized sludge (Schowanek et al., 2007). Aerobic conditions are also restored during sludge transportation, storage and application on agricultural soil, promoting rapid LAS degradation (Jensen, 1999). The first comprehensive regulation to suggest en- hanced monitoring of sludge was the 3rd draft of Directive "Working Document on Sludge" (EU, 2000) published by the European Union in 2000; however, since publication of this document, very few developments on the topic have been fulfilled.

This work provides an important contribution to the concept of introducing EOX and LAS parameters in the monitoring of sludge from WWTPs, as suggested by the "Working Document on Sludge", only partially integrated in some national and regional legislation references (Emilia-Romagna Region, 2005; Italian regulation, 2018).

In this paper, an updated version of a previous study reported by Goi et al. (2006) in the Friuli-Venezia Giulia region (North-East of Italy), the evolution of meaningful characterization parameters in sewage sludge manifested subsequent to upgrading of wastewater treatment processes over an approximately 10-year period was evaluated. In addition, LAS concentration, one of the emerging contaminants in sewage sludge, was also assessed. Due to the increasing stringency of legislation relating to the use of sewage sludge in agriculture, this study may provide a valuable contribution by suggesting the suitability of specific sewage sludges for agricultural reuse and those which, on the contrary, should undergo additional treatment or be forwarded to different final destinations.

\section{MATERIALS AND METHODS}

\subsection{WWTPs and sample collection}

Sewage sludge samples were collected from 10 different municipal WWTPs in the Friuli-Venezia Giulia region (North-East of Italy); the analysed plants were reported as samples 1-10 in Table 1, together with a brief description of the main plant characteristics, including treatment capacity (expressed as population equivalent, P.E.), process units and sludge treatment sequences. It should be noted that the majority of analyzed plants were small-scale plants (P.E. in the range of $850-9,000$ P.E.) mainly involved in the treatment of domestic wastewater, while two medium-scale plants (n. 1 and 2) were also studied: plant n. 1 treated largely municipal wastewater, while plant $n$. 2 treated a mixture of municipal and industrial wastewater, with the main fraction deriving from chlorine-free pulp and paper industry.

The WWTPs analyzed in this study were localized in the same area as the treatment plants investigated in a similar study in 2006 (Goi et al., 2006). Over the last decade, the selected WWTPs have been transformed and upgraded both in size and process units, thus enabling a comparison of how the improvement of wastewater treatment process could affect sewage sludge quality. For each of the studied WWPTs, a representative sample of $5 \mathrm{Kg}$ was collected manually at the end of sludge treatment from a fresh sludge pile of about $50 \mathrm{~kg}$, by filling polyethylene bags. After collection, each sample was labeled and then placed in a cooler box with ice for transport to the laboratory.

\subsection{Sample preparation}

Samples were immediately transported to the laboratory and stored at $4^{\circ} \mathrm{C}$ for subsequent analysis, the samples 
TABLE 1: Main characteristics of the plants considered in the present study.

\begin{tabular}{|c|c|c|c|}
\hline WWTP & Plant size (P.E.) & Wastewater treatment sequence & Sludge treatment sequence \\
\hline Nr. 1 & $>100000$ & Scr. - G.Tr. - O.Rm. - Pr.S.T. - A.S. (N-DN; SBR) - S.Cl. - Disnf. & Thk. - An.Dig. - B.Pr. \\
\hline Nr. 2 & $>100000$ & Scr. - A.S. - S.Cl. - CoTr - Pr.S.T. & Thk. - Aer.Dig. - FP \\
\hline Nr. 3 * & 9000 & Scr. - G.Tr. - A.S. (N-DN) - S.Cl. - Disnf. & Thk. - Aer.Dig. - P.D.Bd. \\
\hline Nr. 4 * & 7500 & Scr. - G.Tr. - A.S. (N-DN) - S.Cl. & Thk. - P.D.Bd. \\
\hline Nr. 5 & 6000 & Scr. - G.Tr. - A.S. (N-DN; IFAS) - S.Cl. & Thk. - D.Bd. \\
\hline Nr. 6 & 5000 & Scr. - G.Tr. - A.S. (N-DN) - S.Cl. - Disnf. & Thk. - Aer.Dig. - D.Bd. \\
\hline Nr. 7 & 4000 & Scr. - G.Tr. - A.S. (N-DN; MBR) & Thk. - D.Bd. \\
\hline Nr. 8 * & 3500 & Scr. - G.Tr. - A.S. (N-DN; MBBR) - S.Cl. & Thk. - P.D.Bd. \\
\hline Nr. 9 & 1500 & Scr. - G.Tr. - A.S. (N-DN) - S.Cl. - Disnf. & Thk. - D.Bd. \\
\hline Nr. 10 * & 850 & Scr. - G.Tr. - A.S. (N-DN; SBR) & P.D.Bd. \\
\hline
\end{tabular}

Legend: P.E. = Population equivalent; Scr. = Screening; G.Tr. = Grit Trap; O.Rm. = Oil removal; Pr.S.T. = Primary settling tank; A.S. = Activated sludge; N-DN = Nitrification-Denitrification; SBR = Sequencing Batch Reactor; MBBR = Moving Bed Biofilm Reactor; IFAS = Integrated Fixed-film Activated Sludge; MBR = Membrane BioReactor; SBR = Sequencing Batch Reactor; S.Cl. = Secondary clarifier; CoTr = Coagulation-flocculation treatment; T.F. $=$ Trickling Filter; Disnf. = Disinfection; Thk. = Thickener; B.Pr. = Belting press; FP = Filter Press; Aer.Dig. = Aerobic digestion; An. Dig. = Anaerobic digestion; $D . B d .=$ Drying bed; $P . D . B d .=$ Pilot Drying bed; $($ Dom $)=$ Domestic wastewater; $($ URB-Dom $)=$ Urban wastewater, mainly domestic; $($ URB-Ind $)=$ Urban wastewater, mainly industrial * = optimal aeration of the sludge was performed usingy a pilot drying bed (P.D.Bd.) for 6 months.

were freeze-dried and passed through a $1 \mathrm{~mm}$ sieve to obtain well homogenized samples. Sewage sludge samples were frozen at $-20^{\circ} \mathrm{C}$, then lyophilised using a Coolsafe 55-4 Touch lyophilizer with $-50^{\circ} \mathrm{C}$ condenser temperature. The ultimate vacuum pressure was 0.4 mbar.

To test potential degradation of LAS over time, a fraction of sludge from the different size WWTPs (samples nr. 3, 4, 8, 10 in Table 1) was placed in a pilot-size aerobic drying bed, where aerobic conditions were maintained by ideal surface venting for 6 months after sludge withdrawal (Table 1).

\subsection{Heavy Metal analysis}

Heavy metal content was determined using the USEPA 3051 method of Inductively Coupled Plasma Atomic Emission Spectroscopy, ICP-AES, (Varian Vista Pro), as performed in Misson et al. (2020). Calibration was performed using standard solutions $(0.5,1,5,10,30,50 \mathrm{ppm})$ prepared from an ICP-standard 23-element solution in 5\% $\mathrm{HNO} 3$ (Merck solution IV), with yttrium (Y) as internal standard. The method detection limit (MDL) was calculated as $3 \mathrm{~s} / \mathrm{m}$ (where $s$ is the standard deviation of 10 replicate blanks and $m$ is the slope of the calibration curve) for each element.

\subsection{EOX analysis}

All samples were freeze-dried, manually sieved through a $1 \mathrm{~mm}$ mesh sieve and grinded in a ball-grinder. Subsequently, $1.0 \mathrm{~g}$ of pre-treated samples were extracted with $5 \mathrm{~mL}$ of solvent (ethyl acetate or $\mathrm{n}$-hexane) by shaking for $24 \mathrm{~h}$. Most of the solvent was separated and then evaporated from the extracts under a nitrogen flow, until only $1 \mathrm{~mL}$ remained; the resulting sample was then refrigerated until time of analysis. Analyses were performed using Trace Elemental Instrument, Euroglas ECS 1000 upgraded with digital coulometer and control software (TEIS). The apparatus consisted of an injection system, a thermal extraction, a trapping section and a titration cell. $100 \mu \mathrm{L}$ of residual extract were introduced into the instrument at an injection rate of $20 \mu \mathrm{L} / \mathrm{min}$, and combustion at $950{ }^{\circ} \mathrm{C}$ was carried out, with pyrolysis of organochlorine compounds and release of hydrogen halides. The reaction gases formed during the combustion process, after water removal with sulphuric acid, were introduced into the titration cell where the halogenated acid (formed during the combustion of organic halogens) created a current which could be measured and related to the global quantity of organic halogen compounds in the extract.

\subsection{LAS analysis}

All measurements were made with a Shimadzu high performance liquid chromatograph LC-20AT (Shimatzu Corporation Kyoto, Japan), fitted with a SIL-20AHT autosampler with a loop $20 \mu \mathrm{L}$, equipped with a diode array detector (DAD), a quaternary pump, a vacuum degasser and a thermostatic column compartment. The analytical cartridge column (thermostated at $35^{\circ}$ ) was a SUPELCOSIL LC-8 (SUPELCO, Bellefonte, PA, USA), $25.0 \mathrm{~cm} \times 4.6$ $\mathrm{mm}$ ID, $5 \mu \mathrm{m}$ particle size. Microwave-assisted extraction (MAE) was performed over a Microwave Mars 5 Digestion Oven apparatus (CEM, North Carolina, USA) on $0.5 \mathrm{~g}$ of dried sewage sludge samples using methanol (HPLC grade by Merck) as solvent (Mortensen et al., 2001; García et al., 2005; Villar et al., 2007; Braguglia et al., 2014) and the extracts filtered through glass wool and analysed by HPLC.

A good resolution of all LAS peaks was obtained using as mobile phase acetonitrile-water containing $0.1 \mathrm{M} \mathrm{Na}$ $\mathrm{ClO}_{4}$ (55:45) and isocratic elution (acetonitrile was HPLC grade by Merck and sodium perchlorate was analytical grade by Sigma Aldrich). Compounds were eluted isocratically for $6 \mathrm{~min}$ at runtime at a flow rate of $0.8 \mathrm{~mL} / \mathrm{min}$ after $20 \mu \mathrm{L}$ injection. Instrumental response was preliminarily tested through use of standard LAS solution (standard solutions with $\mathrm{C} 10-\mathrm{C} 13$ chain length were prepared in ultrapure water), highlighting an excellent HPLC cleaning and separation process. 


\section{RESULTS AND DISCUSSION}

\subsection{Nutrient content and agricultural reutilization potential}

To achieve successful land application, sludge nutrient concentration should be carefully considered. $P$ requirement of most crops is four to ten-fold less than $\mathrm{N}$ needs; moreover, $\mathrm{P}$ is usually present in more bioavailable forms (inorganic). Consequently, to prevent underestimating crops needs, it is important to consider $\mathrm{N}$ requirement when evaluating sludge application rate (Hue, 1995). A comparison with literature data highlighted a wide variation in plant macronutrient concentration in sewage sludge (Table 2). The results obtained on $\mathrm{N}$ content in the present work were coherent with other literature studies, while $\mathrm{P} / \mathrm{N}$ ratio was relatively lower compared to literature studies. (Sommers,1977; Mumma et al., 1988; Mtshali et al., 2014) As shown in Table 2, sewage sludge could be seen as an imbalanced fertilizer due to elutriation of soluble nutrients from sludge during wastewater treatment. For example, $\mathrm{K}$ featured a typical range of $0.1-0.4 \%$ d.w., consequently, to make the sludge more suitable for agricultural reuse, a $\mathrm{K}$ supplement (such as $\mathrm{KCl}$, wood ash and $\mathrm{K}$-rich crop res- idues) would be required (Hue, 1995; Czerska and Smith, 2008; Pakhnenkoa et al., 2009).

\subsection{Heavy Metals}

Heavy metal concentration is one of the most crucial factors of concern in the land reutilization of sludge. For monitoring purposes, the heavy metals to be investigated were chosen in line with the suggestions of the "Working Document on Sludge and Biowaste" (European Union, 2004): "heavy metals are intended as cadmium (Cd), chromium (Cr), copper ( $\mathrm{Cu})$, mercury $(\mathrm{Hg})$, nickel $(\mathrm{Ni})$, lead $(\mathrm{Pb})$ and zinc ( $\mathrm{Zn})$ in metallic form as well as their salts and oxides". The presence of heavy metals is essential for plants and animals, although an excessive concentration of these elements may damage crops and threaten human health by entering the food chain (Usman et al., 2012). Therefore, before land application heavy metal concentrations should meet the limits defined by legislations on sewage sludge management. Table 3 shows the permissible limits for heavy metals suggested by some national legislations and European Council Directive 86/278/EEC (European Commission, 2009), aimed at protecting the environment (in

TABLE 2: Total concentration of selected plant nutrients in sewage sludge

\begin{tabular}{|c|c|c|c|c|c|}
\hline \multirow{2}{*}{ variable } & \multicolumn{5}{|c|}{ Total Nutrient, \% d.w. } \\
\hline & $\mathbf{N}$ & $\mathbf{P}$ & $\mathbf{K}$ & $\mathrm{Ca}$ & $\mathbf{M g}$ \\
\hline \multicolumn{6}{|c|}{ FVG sewage sludge (10 samples) } \\
\hline Range & $3.1-6.8$ & $0.37-1.7$ & $0.17-0.38$ & $1.88-17.13$ & $0.22-4.78$ \\
\hline Mean & 4.21 & 0.93 & 0.27 & 6.88 & 1.95 \\
\hline Median & 4.15 & 0.85 & 0.29 & 5.47 & 1.63 \\
\hline \multicolumn{6}{|c|}{ Sommers, 1977 (250 samples) } \\
\hline Range & $0.5-7.6$ & $1.1-5.5$ & $0.08-1.1$ & $0.6-13.5$ & $0.03-1.1$ \\
\hline Mean & 4.9 & 2.9 & 0.52 & 3.3 & 0.52 \\
\hline Median & 4.8 & 2.7 & 0.3 & 3 & 0.41 \\
\hline \multicolumn{6}{|c|}{ Mumma et al., 1988 (15 samples) } \\
\hline Range & $1.19-4.93$ & $0.22-3.13$ & $0.03-0.46$ & $0.32-15.9$ & $0.04-0.81$ \\
\hline Mean & 2.9 & 1.2 & 0.19 & 3.92 & 0.35 \\
\hline Median & 2.78 & 0.78 & 0.15 & 2.17 & 0.34 \\
\hline \multicolumn{6}{|c|}{ Mtshali et al., 2014 (7 samples) } \\
\hline Range & $0.5-4.5$ & $0.7-2.5$ & $0.04-0.49$ & $0.12-1.59$ & $0.04-0.43$ \\
\hline Mean & 2.47 & 1.69 & 0.15 & 0.92 & 0.22 \\
\hline
\end{tabular}

TABLE 3: Selected National and EU permissible limits of heavy metals in sludge for agricultural use (mg/kg d.w.) (EC 2009; Stylianou et al., 2008; Italian regulation, 2018).

\begin{tabular}{|c|c|c|c|c|}
\hline Element & Limit 86/278/EEC & Limit Italy & Limit Netherlands & Limit France \\
\hline $\mathrm{Cd}$ & $20-40$ & 20 & 1.25 & 20 \\
\hline $\mathrm{Cr}$ & - & 200 & 75 & 1000 \\
\hline $\mathrm{Cu}$ & $1000-1750$ & 1000 & 75 & 1000 \\
\hline $\mathrm{Hg}$ & $16-25$ & 10 & 0.75 & 10 \\
\hline $\mathrm{Ni}$ & $300-400$ & 300 & 30 & 200 \\
\hline $\mathrm{Pb}$ & $750-1200$ & 750 & 100 & 800 \\
\hline $\mathrm{Zn}$ & $2500-4000$ & 2500 & 300 & 3000 \\
\hline
\end{tabular}


TABLE 4: Heavy metal concentrations in the analysed sludge (mg/kg d.w.)

\begin{tabular}{|c|c|c|c|c|c|c|c|}
\hline Sample & Cd & $\mathrm{Cr}$ & $\mathrm{Cu}$ & $\mathrm{Hg}$ & $\mathrm{Ni}$ & $\mathrm{Pb}$ & Zn \\
\hline Italian limits (mg/kg d.w) & 20 & 200 & 1000 & 10 & 300 & 750 & 2500 \\
\hline SS no.1 & 2.12 & 59.54 & 339.54 & 2.12 & 36.67 & 92.19 & 1265.97 \\
\hline SS no.2 & 0.74 & 17.74 & 53.61 & 0.54 & 13.06 & 12.78 & 109.56 \\
\hline SS no.3 & 1.17 & 48.07 & 584.11 & 1.36 & 31.20 & 63.81 & 555.47 \\
\hline SS no.4 & 0.51 & 32.27 & 189.89 & 0.12 & 20.86 & 24.59 & 190.57 \\
\hline SS no.5 & 1.01 & 35.17 & 302.42 & 0.47 & 18.86 & 38.58 & 436.07 \\
\hline SS no.6 & 1.65 & 194.17 & 593.48 & 0.36 & 78.81 & 81.16 & 1446.43 \\
\hline SS no.7 & 0.88 & 39.71 & 237.65 & 0.20 & 24.76 & 43.45 & 309.37 \\
\hline SS no.8 & 0.94 & 22.58 & 146.29 & 0.07 & 11.56 & 24.66 & 586.92 \\
\hline SS no.9 & 1.44 & 41.97 & 427.55 & 0.39 & 27.24 & 87.21 & 795.75 \\
\hline SS no.10 & 1.97 & 239.63 & 347.45 & 6.40 & 46.61 & 76.78 & 5676.40 \\
\hline mean & 1.24 & 73.08 & 322.20 & 1.20 & 30.96 & 54.52 & 1137.25 \\
\hline median & 1.09 & 40.84 & 320.98 & 0.43 & 26.00 & 53.63 & 571.19 \\
\hline
\end{tabular}

particular soil) when sewage sludge is applied on land for agricultural purposes.

$\mathrm{HM}$ concentrations in sludge samples investigated in this study are illustrated in Table 4. As shown in Table 4, heavy metal concentrations in all tested samples were below the maximum permitted limits (Table 3), thus promoting agricultural reuse of the analysed sludge. The only exceptions were $\mathrm{Cr}$ and $\mathrm{Zn}$ concentrations in sample no. 10 (239.63 and $5,676.4 \mathrm{mg} / \mathrm{kg}$ respectively), likely due to the advanced wastewater treatment in plant no. 10. Indeed, plant no. 10 is a small WWTP applying nitrification-denitrification in a sequential batch reactor (SBR); in this kind of process, sludge remains in the tank over extended periods, leading to a significant metal adsorption on the sludge itself.

Generally, the concentration of heavy metals in sludge is affected by the treatment plant potentiality and type of influent wastewater, i.e. domestic or industrial (Spanos et al., 2016; Chanaka Udayanga et al., 2018). Process upgrading in the wastewater treatment circuit may lead to an increase of metal content in the sludge. In practice, comparing actual data with the previous study by Goi et al. (2006) in the same area, a general rise in maximum measured $\mathrm{HM}$ concentrations was observed (Figure 1).
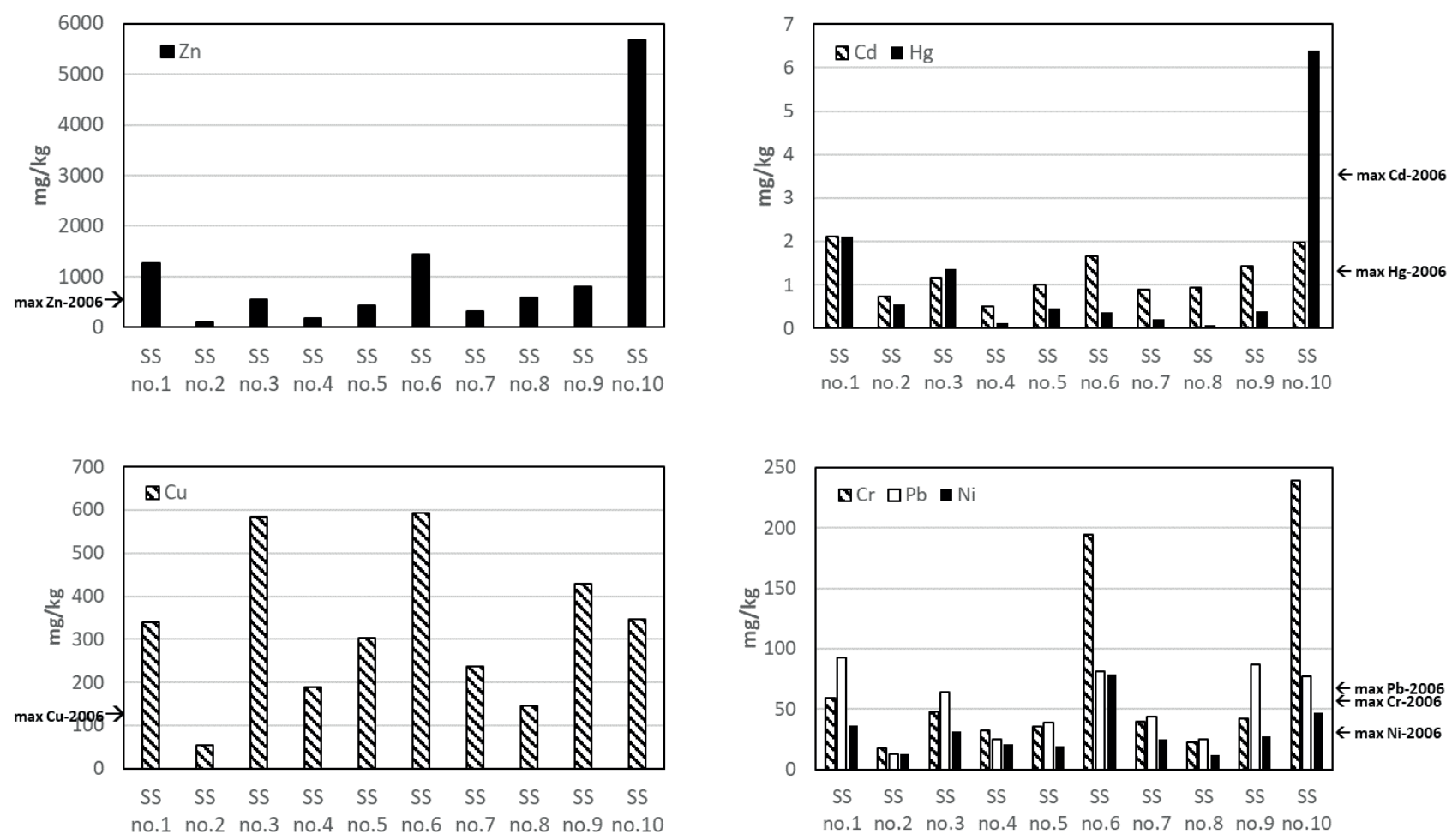

FIGURE 1: Heavy metal concentration in sludge samples and maximum values found in 2006 monitoring campaign. 

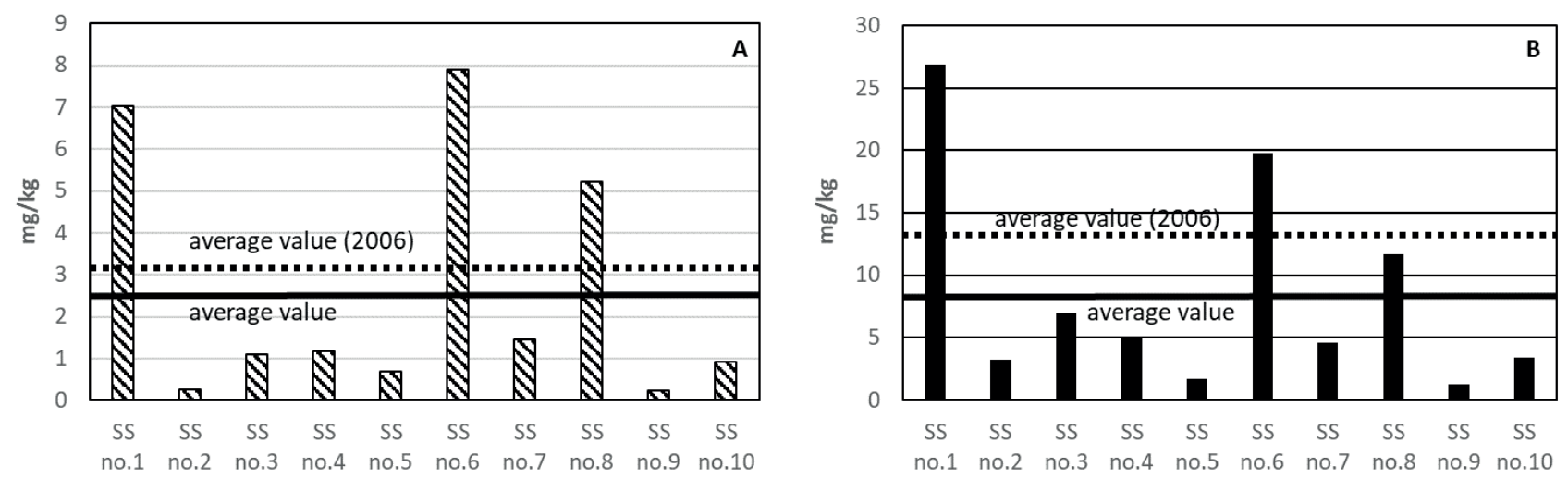

FIGURE 2: EOX concentration measures (A- Hexane extraction; B- ethyl acetate extraction) in sludge samples and average values comparison with 2006 campaign.

This interesting outcome could be explained by the process upgrade and plant revamping undertaken in the studied WWTPS over the last decade. These improvements in wastewater treatment processes have maximized the efficiency of contaminant removal from wastewater, allowing a larger transport of metals into residual solid fraction.

\subsection{EOX}

Over the last two decades considerable interest has focussed on data relating to the occurrence, behaviour and fate of organohalogen compounds in water, sludge and the environment. The presence of organic halogen compounds in sludge was a key point in the new EU proposed monitoring (European Union, 2004). These compounds, in fact, are highly persistent and do not degrade over time; moreover, they are not absorbable by the soil (especially polar compounds) and consequently directly reach the groundwater, leading to water contamination. Therefore, a sludge with high concentrations of these harmful compounds is generally deemed unsuitable for agricultural reuse (Rizzardini and Goi, 2014).

As well as the singular toxicity of the individual compounds monitored, the utilization of EOX as a sum parameter to obtain global information is a very interesting perspective in monitoring organic halogen content in soils. Moreover, as already observed in a previous case study (Goi et al. 2006), the EOX parameter may be of importance in quality control for the choice of sludge processing routes.

EOX concentrations in the analysed sewage sludge samples, obtained both by hexane and ethyl acetate extraction, are presented in Figure 2 and Table 5. The maximum concentration of EOX found in the present work was $26.86 \mathrm{mg} / \mathrm{kg}$ (related to sample no. 1), extracted by ethyl acetate. This EOX content was associated to the largest WWTP with combined municipal and urban sewage sources; EOX concentrations in small municipal WWTPs usually displayed low values in this monitoring campaign, with the exception of samples 6 and 8. At variance with the HM assay, maximum EOX values measured in the actual samples were comparable to those of the previous monitoring campaign.

The measured EOX content in ethyl acetate extractions was 2-6 times higher when compared with hexane extractions, in agreement with the results reported by Reemtsma and Jekel (1996). This suggested that polar halogenated molecules were present in larger quantities than non-polar compounds (i.e. non-polar compounds could only be extracted by ethyl acetate).

TABLE 5: EOX and LAS concentration in sludge samples from analysed WWTPs (mg/kg d.w.)

\begin{tabular}{|c|c|c|c|c|c|c|}
\hline \multirow{2}{*}{ Sample } & \multirow{2}{*}{ LAS } & \multirow{2}{*}{ CV\% } & \multicolumn{4}{|c|}{ EOX } \\
\hline & & & By hexane & CV\% & By ethyl acetate & $\mathrm{CV} \%$ \\
\hline SS no.1 & 574.41 & 9.6 & 7.03 & 5.34 & 26.86 & 1.26 \\
\hline SS no. 2 & 136.36 & 14.8 & 0.25 & 45.02 & 3.26 & 38.8 \\
\hline SS no. 3 & 180.95 & 14.1 & 1.11 & 20.57 & 6.95 & 4.27 \\
\hline SS no. 4 & 53.75 & 26.3 & 1.17 & 28.6 & 4.98 & 5.88 \\
\hline SS no. 5 & 523.45 & 23.6 & 0.69 & 55.17 & 1.74 & 11.89 \\
\hline SS no.6 & 220.27 & 22.7 & 7.89 & 16.00 & 19.81 & 7.73 \\
\hline SS no.7 & 301.57 & 12.4 & 1.46 & 15.13 & 4.56 & 5.08 \\
\hline SS no.8 & 55.88 & 17.3 & 5.22 & 7.83 & 11.7 & 14.4 \\
\hline SS no.9 & 427.76 & 9.2 & 0.24 & 31.66 & 1.24 & 24.19 \\
\hline SS no. 10 & 138.12 & 16.3 & 0.93 & 11.76 & 3.38 & 3.77 \\
\hline
\end{tabular}


EOX monitoring in sludge from WWTPs in the considered area showed a general persistence of halogenic contamination. Upgrading of the treatment plant process apparently produced no visible effect on EOX degradation. However, a general reduction in average EOX concentration was discernible compared to the previous monitoring study (Figure 2).

\subsection{LAS}

Due to the extensive use of surfactants, specifically LAS, in domestic and industrial applications, their presence in sewage sludge is assured (Granatto et al., 2019). Moreover, these compounds can only be partly degraded in WWTPs, with the extent of degradation largely depending on a) LAS content in raw sewage, b) sludge age after storage and c) process nature (i.e. whether the process is aerobic or anaerobic). Therefore, a measurable portion of LAS invariably accumulates in soils and consequently monitoring of these compounds in sludge is extremely important (Villar et al, 2007).

In Europe LAS concentration in sewage sludge lies between $<1 \mathrm{~g} / \mathrm{kg}$ d.w. and $30 \mathrm{~g} / \mathrm{kg}$ d.w. (Gawlik and Bidoglio, 2006). Table 5 and Figure 3 show the measured LAS concentration in the analysed sludge samples. The lowest concentrations were found in samples 4 and 8 (55.88 and $53.75 \mathrm{mg} / \mathrm{kg}$, respectively), while the highest amount was highlighted in sample no. $1(574.41 \mathrm{mg} / \mathrm{kg})$. Stock et al. (2002) analysed more than 150 sludge samples from different WWTPs in a comprehensive study in Westphalia (Germany). They found a correlation between WWTPs size and LAS concentration; it should be underlined that extended aerobic sludge treatment is common in smaller treatment plants and enhances reduction in LAS concentration.

In accordance with the above, LAS concentration in sample 2 (treated by aerobic digestion) was three times lower than sample 1(treated by anaerobic digestion) for equal WWTPs size. The present study demonstrated that LAS content was lower in sludge treated in pilot drying beds, with optimal aeration, or by aerobic digestion process. It is noteworthy that LAS mean concentration was significantly lower than limit values proposed in the "Working Document on Sludge" (EU, 2000).

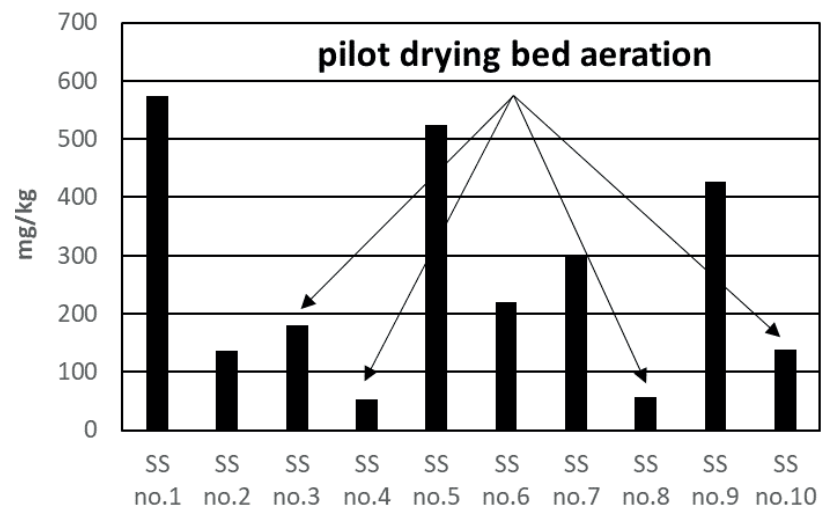

FIGURE 3: LAS concentration in sludge samples from analysed WWTPS.

To summarize, the quality of the investigated sludge (in terms of HM, EOX and LAS) depended on multiple factors, including plant size (PE), type of treated water (Dom., Ind., or Urb.), wastewater treatment process and sludge treatment sequence. It was not possible to directly correlate each parameter to sludge pollution, as all these variables were strictly interconnected and strongly matrix-dependent. Despite the differences and variability present in the analysed parameters, all investigated sludge samples complied with Italian limits suggested by the regulations for agricultural reuse.

Comparison with a previous study (Goi et al., 2006) highlighted a crucial factor: the progressive improvement in wastewater treatment seems to promote a higher concentration of several harmful pollutants in sludge. When HM, EOX and LAS were monitored together, it was found that the more efficient the wastewater treatment line, the higher the inorganic/organic substances transferred to the sludge (Figure 4). This outcome suggests adopting a critical approach to further process development in wastewater treatment lines, considering future perspectives in sludge agricultural reuse together with the need to develop alternative final destination routes, such as thermal processes (incineration, pyrolysis, gasification, hydrothermal treatment) (Chanaka Udayanga et al., 2018). Teoh and Li

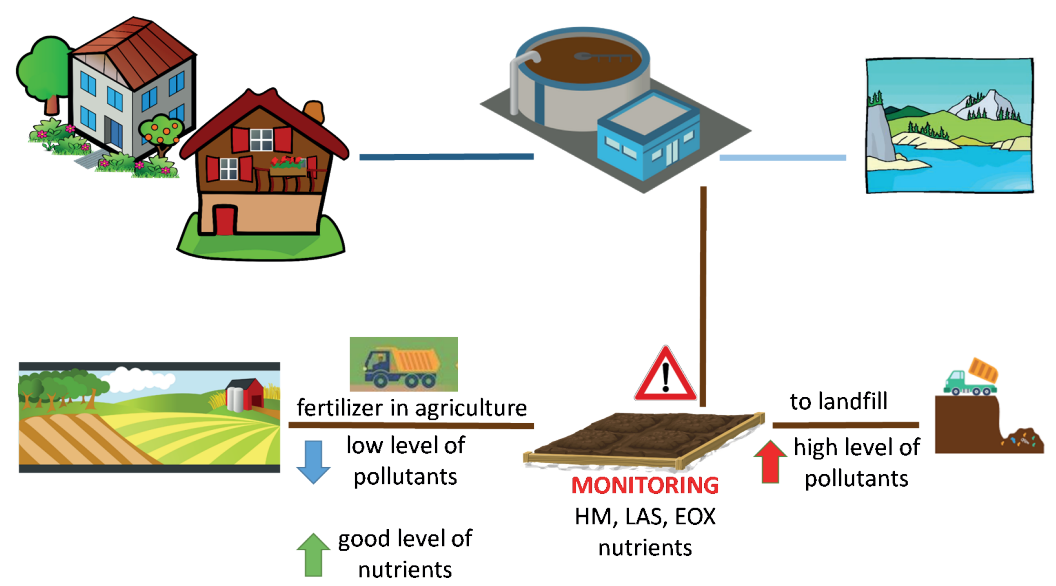

FIGURE 4: Proposed scheme for sludge checking, to prevent the risk of soil and groundwater contamination in the agricultural reuse of contaminated sludge (considering HM, EOX, LAS). 
(2020) studied alternative sludge treatment methods applying Life Cycle Assessment (LCA); the investigated aspects were sludge volume, pollutants, global warming and toxicity. It was concluded that anaerobic digestion, pyrolysis and supercritical water oxidation were the best-performing treatment methods (Teoh and Li, 2020), suggesting that a differentiated approach is highly recommended in sludge treatment and valorization, enhancing the recovery of both energy and material, whilst at the same time reducing environmental contamination hazards.

\section{CONCLUSIONS}

Subsequent to the increasing diffusion of wastewater treatment, particularly in high- and middle-income countries, the sewage sludge generated should be treated and valorised in an ecological and economic way, thus contributing to the circular economy. While wastewater treatment plants are effective in removing pollutants from water, they accumulate heavy metals and other persistent toxic compounds in sludge, thus restricting its potential reuse. In this study, HM, EOX and LAS, three main limiting factors for the land application of sewage sludge, were monitored in sewage sludge samples from 10 different low-middle capacity wastewater treatment plants in the Friuli-Venezia Giulia region (North-East of Italy). The results showed how the concentration of these compounds was much lower than permissible limits suggested by Council Directive 86/278/ EEC for the agricultural reuse of sewage sludge, in particular in sludge originating from small municipal plants. Sewage sludge from the studied wastewater treatment plants could be used for sustainable agriculture, exploiting its macro and micronutrient content, without posing a threat for the environment and human health. On the other hand, the present study highlighted a future scenario in which a continuous progress in wastewater treatment, by decreasing pollutant levels released to the receptor body and thus improving water quality, would transfer higher quantities of potentially harmful compounds to the sewage sludge, rendering it unsafe for agricultural reuse. This study, also in view of a similar monitoring campaign performed in 2006, questioned the future possibility of reusing sewage sludge in agricultural applications. Moreover, it raised the need for further constant and regular sludge control, with the specific aim of preventing the agricultural reuse of sludge contaminated with organic and inorganic substances (HM, EOX, LAS), and associated risks of soil and groundwater contamination, as well as potential entrance into the food chain.

\section{ACKNOWLEDGEMENTS}

The authors thank Andrea Milocco of CAFC Spa and Paolo Dreossi of Acquedotto Poiana Spa, together with all the personnel of their Water Companies for help in this study.

\section{REFERENCES}

Abis, M., Calmano, W., Kuchta, K., 2018. Innovative technologies for phosphorus recovery from sewage sludge ash. Detritus. 1, 23-29. https://doi.org/10.26403/detritus/2018.23.
American Society of Civil Engineers (ASCE) and American Water Works Association (AWWA), 1996. Technology Transfer Handbook: Management of Water Treatment Plant Residuals. ASCE Publications, Denver (CO). https://nepis.epa.gov/Exe/ZyPURL.cgi?Dockey=30004PIO.TXT.

Anjum, M., Al-Makishah, N.A., Barakat, M.A., 2016. Wastewater sludge stabilization using pre-treatment methods. Process Saf. Environ. 102, 615-632. https://doi.org/10.1016/j.psep.2016.05.022.

Ashekuzzaman, S.M., Forrestal, P., Richards, K., Fenton, O., 2019. Dairy industry derived wastewater treatment sludge: Generation, type and characterization of nutrients and metals for agricultural reuse. J. Clean. Prod. 230, 1266-1275. https://doi.org/10.1016/j. jclepro.2019.05.025.

Braguglia, C.M., Carozza, N., Coors, A., Gallipoli, A., Gianico, A., GuilIon, E., Kunkel, U., Mascolo, G., Richter, E., Tomei, M.C., Ternes, T.A., Mininni, G., 2014. Quality assessment of digested sludges produced by advanced stabilization processes. Environ. Sci. Pollut. Res. 22, 7216-7235. https://doi.org/10.1007/s11356-014-3090-6.

Chanaka Udayanga, W.D., Veksha, A., Giannis, A., Lisak, G., Chang, V.W.C., Lim, T.T., 2018. Fate and distribution of heavy metals during thermal processing of sewage sludge. Fuel 226, 721-744. https:// doi.org/10.1016/j.fuel.2018.04.045.

Chen, Z., Hu, S., 2019. Heavy metals distribution and their bioavailability in earthworm assistant sludge treatment wetland. J. Hazard. Mater. 366, 615-623. https://doi.org/10.1016/j.jhazmat.2018.12.039.

Collivignarelli, M.C., Abbà, A., Benigna, I., 2020. The reuse of biosolids on agricultural land: Critical issues and perspective. Water Environ. Res. 91(1), 11-25. https://doi.org/10.1002/wer.1196

Contreras Lopez, M.C., 2003. Determination of potentially bioaccumulating complex mixtures of organochlorine compounds in wastewater: a review. Environ. Int. 28, 751-759. https://doi.org/10.1016/ S0160-4120(02)00120-4.

Czerska A., Smith S. R. (2008) Effects of air-drying and storing sewage sludge biosolids on enteric pathogens, indicators and nutrients. Centre for Environmental Control and Waste Management Department of Civil and Environmental Engineering. https://waterportal. com.au/swf/images/swf-files/419---003-biosolids-literature-review.pdf.

Di Maria, F., Ayalon, O., Daskal, S., 2018. Biodegradable waste management by anaerobic digestion: a comparison between policy approaches and regulation in Italy and Israel. Detritus. 3, 58-67. https://doi.org/10.31025/2611-4135/2018.13721.

European Commission, 2009. Environmental, economic and social impacts of the use of sewage sludge on land. Consultation Report on Options and Impacts, Report by RPA, Milieu Ltd and WRc for the European Commission, DG Environment, European Commission.

European Union, 2000: Working Document on Sludge, Third Draft, 27 April 2000. Brussels, Belgium.

European Union, 2004: Working Document on Sludge and Biowaste, EUROPEAN COMMISSION DIRECTORATE-GENERAL ENVIRONMENT, Directorate A - Communications, Governance, Production, Consumption and Waste, ENV.A2 - Production, Consumption \& Waste, Brussels, 18 December 2003, DG ENV.A.2/LM.

Eurostat, Sewage sludge production and disposal, last update 19.11.2018. https://ec.europa.eu/eurostat/web/products-datasets/product?code=env_ww_spd

Emilia Romagna Region: Determination of General Director of environment, soil and coast preservation n. 11046 of 29/07/2005. BUR Emilia Romagna n.120 of 29/08/2005. http://bur.regione.emilia romagna.it/archivio/bollettino_download?anno=2005\&num_ boll=120.

Fijalkowski, K., Rorat, A., Grobelak, A., Kacprzak, M.J., 2017. The presence of contaminations in sewage sludge - the current situation. J. Environ. Manage. 203, 1126-1136. https://doi.org/10.1016/j. jenvman.2017.05.068.

García, M.T., Campos, E., Ribosa, I., Latorre, A., Sánchez-Leal, J., 2005. Anaerobic digestion of linear alkyl benzene sulfonates: biodegradation kinetics and metabolite analysis. Chemosphere 60, 16361643. https://doi.org/10.1016/j.chemosphere.2005.02.048.

Gawlik, B.M., Bidoglio, G., 2006. Background values in European soils and sewage sludges. Part I European Commission, Brussels.

Gherghel, A., Teodosiu, C., De Gisi, S., 2019. A review on wastewater sludge valorisation and its challenges in the context of circular economy. J. Clean. Prod. 228, 244-263. https://doi.org/10.1016/j. jclepro.2019.04.240.

Goi, D., Tubaro, F., Dolcetti, G., 2006. Analysis of metals and EOX in sludge from municipal wastewater treatment plants: A case study. Waste Manage. 26, 167-175. https://doi.org/10.1016/j.wasman.2005.03.006. 
Gondek, K., Kopec, M., Mierzwa, M., Tabak, M., Chmiel, M., 2014. Chemical and biological properties of composts produced from organic waste. J. Elementol. 19, 377-390. https://doi.org/10.5601/ jelem.2014.19.2.670

Granatto, C.F., Macedo, T.Z., Gerosa, L.E., Sakamoto, I.K., Silva, E.L., Varesche, M.B.A., 2019. Scale-up evaluation of anaerobic degradation of linear alkylbenzene sulfonate from sanitary sewage in expanded granular sludge bed reactor. Int. Biodeterior. Biodegradation. 138, 23-32. https://doi.org/10.1016/j.ibiod.2018.12.010.

Haarlemmer, G., Briand, M., Roubaud, A., Roussely J., Dénie M., 2018. Economic evaluation of a hydrothermal liquefaction process. Detritus. 3, 84-92. https://doi.org/10.31025/2611-4135/2018.13695.

Hargreaves, A., Constantino, C., Dotro, G., Cartmell, E., Campo, P., 2018. Fate and removal of metals in municipal wastewater treatment: a review. Environ. Technol. Rev. 7, 1-18. https://doi.org/10.1080/21 622515.2017 .1423398$.

Hu, S., She, X., Wei, X., Hu, B., Hu, C., Qian, Y., Fang, Y., Zhang, X., Bashir, S. Chen, Z., 2017. Surplus sludge treatment in two sludge treatment beds under subtropical condition in China. Int. Biodeter. Biodegrad. 119, 377-386. http://dx.doi.org/10.1016/j.ibiod.2016.11.005.

Hue, N.V., 1995. Sewage sludge. Rechcigl J.E. (Ed.), Soil Amendments and Environmental Quality, Lewis Publishers, Florida, 199-247.

Italian regulation, 2018. Legge n. 130 del 16/11/2018, articolo 41 https://www.gazzettaufficiale.it/eli/id/2018/09/28/18G00137/sg.

Jensen, J., 1999. Fate and effects of linear alkylbenzene sulphonates (LAS) in the terrestrial environment. Sci. Total Environ. 226, 93111. https://doi.org/10.1016/S0048-9697(98)00395-7.

Kannan, K., Kawano, M., Kashima, Y., Matsui, M., Giesy, J.P., 1999. Extractable organohalogens (EOX) in sediment biota collected at an Estuarine March near a former chloroalkali facility. Environ. Sci. Technol. 33, https://doi.org/1004-1008. 10.1021/es9811142.

Laura, F., Tamara, A., Muller, A., Hiroshan, H., Christina, D., Serena, C. 2020. Selecting sustainable sewage sludge reuse options through a systematic assessment framework: Methodology and case study in Latin America. J. Clean. Prod. 242, 118389. https://doi. org/10.1016/j.jclepro.2019.118389.

Misson, G., Mainardis, M., Incerti, G., Goi, D., Peressotti, A., 2020. Preliminary evaluation of potential methane production from anaerobic digestion of beach-cast seagrass wrack: The case study of high-adriatic coast. J. Clean. Prod. 254, 120131. https://doi. org/10.1016/j.jclepro.2020.120131.

Mortensen, G.K., Egsgaard, H., Ambus, P., Jensen, E.S., Grøn, C., 2001. Influence of Plant Growth on Degradation of Linear Alkylbenzene Sulfonate in Sludge-Amended Soil. J. Environ. Quality 30, 12661270. https://doi.org/10.2134/jeq2001.3041266x.

Mtshali, J.S., Tiruneh, A.T., Fadiran, A.O., 2014. Characterization of Sewage Sludge Generated from Wastewater Treatment Plants in Swaziland in Relation to Agricultural Uses. Res. Environ. 4, 190-199. doi:10.5923/j.re.20140404.02

Mumma, R.D., Rashid, K.A., Raupach, D.C., Shane, B.S., Scarlet-Kranz, J.M., Bache, C.A., Gutenmann, W.H., Lisk D.J., 1988. Mutagens, toxicants, and other constituents in small city sludges in New York State. Arch. Environ. Contam. Toxicol. 17, 657. https://doi. org/10.1007/BF01055835

Niemirycz, E., Kaczmarczyk, A., Blažejowski, J., 2005. Extractable organic halogens (EOX) in sediments from selected Polish rivers and lakes-a measure of the quality of the inland water environment. Chemosphere 61, 92-97. https://doi.org/10.1016/j. chemosphere.2005.03.071.

Pakhnenko E. P., Ermakov A. V., Ubugunov L. L. (2009) Influence of sewage sludge from sludge beds of Ulan-Ude on the soil properties and the yield and quality of potatoes. Moscow University Soil Science Bulletin. 64, 175-181. https://doi.org/10.3103/ S0147687409040061.

Pires, A.M.M., Mattiazzo, M.E., 2003. Bio solids conditioning and the availability of $\mathrm{Cu}$ and $\mathrm{Zn}$ for rice. Sci. Agric. 60, 161-166. http:// dx.doi.org/10.1590/S0103-90162003000100024.

Quian, L., Wang, S., Xu, D., Guo, Y., Tang, X., Wang, L., 2016. Treatment of municipal sewage sludge in supercritical water: a review. Water Res. 89, 118-131. http://dx.doi.org/10.1016/j.watres.2015.11.047.

Reemtsma, T., Jekel, M., 1996. Potential of ethyl acetate in the determination of extractable organic halogens (EOX) from contaminated soil, sediment, and sewage sludge. Chemosphere 32, 815-826. https://doi.org/10.1016/0045-6535(95)00369-X
Rizzardini, C.B., Goi, D., 2014. Sustainability of Domestic Sewage Sludge Disposal. Sustainability 6, 2424-2434. http://dx.doi. org/10.3390/su6052424

Rodziewicz, M., Kaczmarczyk, A., Niemirycz, E., 2004. Poly-chlorinated biphenyls in sediments of the Odra River and its tributaries. Polish J. Environ. Studies 13, 203-208.

Romanos, D., Nemer, N., Khairallah, Y., Abi Saab, M.T., 2019. Assessing the quality of sewage sludge as an agricultural soil amendment in Mediterranean habitats. Int. J. Recy. Organ. Waste Agr. 8, 377-383. https://doi.org/10.1007/s40093-019-00310-x.

Schowanek, D., David, H., Francaviglia, R., Hall, J., Kirchmann, H., Krogh, P.H., Schraepen, N., Smith, S., Wildemann, T., 2007. Probabilistic risk assessment for linear alkylbenzene sulfonate (LAS) in sewage sludge used on agricultural soil. Regulatory Toxicology and Pharmacology 49, 245-259. https://doi.org/10.1016/j. yrtph.2007.09.001

Singh, K.P., Mohan, D., Sinha, S., Dalwani, R., 2004. Impact assessment of treated/untreated wastewater toxicants discharged by sewage treatment plants on health, agricultural, and environmental quality in the wastewater disposal area. Chemosphere 55, 227-255. https://doi.org/10.1016/j.chemosphere.2003.10.050

Singh, R.P., Agrawal, M., 2008. Potential benefits and risks of land application of sewage sludge. Waste Manage. 28, 347-358. https://doi. org/10.1016/j.wasman.2006.12.010.

Sommers, L. E., 1977. Chemical composition of sewage sludges and analysis of their potential use as fertilizers. J. Environ. Quality 6(2), 225-232. https://doi.org/10.2134/ jeq1977.00472425000600020026x.

Sorme, L., Lagerkvist, R., 2002. Sources of heavy metals in urban wastewater in Stockholm. Sci. Tot. Environ. 298, 131-145. https:// doi.org/10.1016/S0048-9697(02)00197-3.

Spanos, T., Ene, A., Styliani Patronidou, C., Xatzixristou, C., 2016. Temporal variability of sewage sludge heavy metal content from Greek wastewater treatment plants. Ecol. Chem. Eng. S. 23, 271-283. https://doi.org/10.1515/eces-2016-0019.

Stock, H.-D., Alberti, J., Reupert, R.R., Hoffmann-Nogai, C., Oberdörfer, M. und Delschen, T., 2002. Umweltrelevante Schadstoffe in Klärschlämmen, Dünger und Kompost in Nordrhein-Westfalen.

Teoh, S.K., Li, L.Y., 2020. Feasibility of alternative sewage sludge treatment methods from a lifecycle assessment (LCA) perspective. J. Clean. Prod. 247, 119495. http://dx.doi.org/10.1016/j.jclepro.2019.119495.

Vorkommen, Eigenschaften und Verhalten. In: 35. Essener Tagung für Wasser- und Abfallwirtschaft vom 20.3.-22.3.2002 in Essen. Tei II. (Dohmann M., Institut für Siedlungswasserwirtschaft der RWTH Aachen, (Hrsg.), S. 67/1-67/26

Stylianou, M., Inglezakis, V., Moustakas, K., Loizidou, M., 2008 Improvement of the quality of sewage sludge compost by adding natural clinoptilolite. Desalin. 224, 240-249. https://doi.org/10.1016/j. desal.2007.06.009.

Tsybina, A., Wuensch, C., 2018 Analysis of sewage sludge thermal treatment Methods in the context of circular economy. Detritus. 2 3-15. https://doi.org/10.31025/2611-4135/2018.13668.

USEPA (1995). National Ambient Air Quality Standards. http://www. epa.gov/oagps001.

Usman, K., Khan, S., Ghulam, S., Khan, M.U., Khan, N., Khan, M.A., Khalil, S. K., 2012. Sewage sludge: an important biological resource for sustainable agriculture and its environmental implications. Am. J. Plant Sci. 3, 1708-1721. http://dx.doi.org/10.4236/ ajps.2012.312209.

Valentín, L., Nousiainen, A., Mikkonen, A., 2013. Introduction to Organic Contaminants in Soil: Concepts and Risks. In: Vicent T., Camina G., Eljarrat E., Barceló D. (eds) Emerging Organic Contaminants in Sludges. The Handbook of Environmental Chemistry, vol 24. Springer, Berlin, Heidelberg.

Villar, M., Callejon, M., Jimenez, J. C., Alonso, E., Guiraum, A., 2007. Optimization and validation of a new method for analysis of linear alkylbenzene sulfonates in sewage sludge by liquid chromatography after microwave-assisted extraction. Anal. Chim. Acta 599, 92-97. https://doi.org/10.1016/j.aca.2007.07.065.

Yoshida, H., ten Hoeve, M., Christensen, T.H., Bruun, S., Jensen, L.S., Scheutz, C., 2018. Life cycle assessment of sewage sludge management options including long-term impacts after land application. J. Clean. Prod. 174, 538-547. https://doi.org/10.1016/j.jclepro.2017.10.175 